\title{
Performance of Midwives with Self Management as a Mediator from the Influence of Individual Factors \\ by Bringiwatty Batbual
}

Submission date: 19-Aug-2020 06:37PM (UTC+0800)

Submission ID: 1371354201

File name: Performance_of_Midwives_with_Self_Management_as_a.pdf (378.85K)

Word count: 3092

Character count: 17085 


\title{
Performance of Midwives with Self Management as a Mediator from the Influence of Individual Factors
}

\author{
Bringiwatty Batbual ${ }^{1,3}$, Fendy Suhariadi., M.T. Psikolog' ${ }^{2}$ Nyoman Anita Damayanti, Drg, M.S. ${ }^{2}$, \\ Dra. Linda Augustien Makalew, M.Kes. ${ }^{4}$ \\ ${ }^{I}$ Doctoral Student, Department of Health Promotion and Behavior Science, Faculty of Public Health, Airlangga \\ University, Surabaya, ${ }^{2}$ Lecturer at The Faculty of Psychology, Airlangga University, Surabaya, ${ }^{3}$ Lecturer of \\ Midwifery, Polytechnic of Health, Kupang, ${ }^{4}$ Lecturer of Health Analyst, Polytechnic of Health, Manado, Indonesia
}

\begin{abstract}
The performance of midwives is very influential on the performance of the organization in an effort to achieve its goals optimally. This study aims to prove that individual factors in the form of knowledge and skills with self management as mediation influence the performance of midwives in midwifery services at Kupang District Health Centers. Quantitative research with a cross-sectional study design conducted in 26 Puskesmas in Kupang Regency, with a sample of 220 implementing midwives, using the sampling method by simple random sampling. Descriptive statistical analysis, hypothesis testing with PLS. The results of this study prove that the skills of midwives have a significant effect on self management and midwife performance. Knowledge and skills of midwives with self management as mediation have a significant effect on the performance of midwives. Individual factors (knowledge and skills) directly and indirectly influence the performance of midwives with self-management as mediation.
\end{abstract}

Keywords: Performance of Midwives, Self Management.

\section{Introduction}

Health workers who function to provide quality health services are required to play an optimal role according to their main tasks, roles and functions ${ }^{(1)}$. Health workers as health care providers can be measured in performance through various indicators, one of which is through patient satisfaction as recipients of health services $^{(2)}$.

Performance is the result of work that has a strong relationship with the objectives of organizational strategy, customer satisfaction and economic contribution. Willingness and skill are not effective enough to do something without a clear understanding of what is done and how to do $\mathrm{it}^{(3)}$. Human resources

\section{Corresponding Author:}

Linda Augustien Makalew

Polytechnic of Health, Manado, Indonesia, Address: Jl.

R. W. Monginsidi Malalayang, Manado, Indonesia

e-mail: linda.makalew@poltekkesmanado.ac.id who are talented, qualified, highly motivated and willing to cooperate in teams will be the key to the success of the organization. Therefore the leader must be able to set work goals that will produce high-quality, highly motivated and productive employees. Specific target setting in a certain period of time is not only quantitative but also qualitative. Strategies to achieve performance targets, for example by self-development to master the knowledge and expertise needed with an improved level of competence. One effort to find out the ability of an individual in his work is to measure performance according to competency standards carried out continuously and effectively and efficiently. Performance measurement that is commonly used is the measurement of employee performance assessed by direct supervisor, peer rating and self-rating ${ }^{(4)}$.

Midwives as one of the leading health workers are also required to show optimal performance. Midwifery is a science that is formed from the synthesis of multidisciplines related to midwifery services including medicine, nursing, social, behavioral, cultural, public health, and management. 
Kupang Regency with a population of 305,548 people, couples of childbearing age 46,404 couples, the number of pregnant women in 2014 was 8115 mothers. The proportion of village midwives reached $83.33 \%$ (289 midwives) with placements that were almost evenly distributed in all villages in the Kupang Regency area. Nonetheless, the coverage of delivery assistance by health workers is still very low at $50.79 \%$ with the number of mothers giving birth as many as 7746 people. The low coverage of delivery assistance by health workers can result in high MMR and IMR. Maternal mortality in Kupang Regency in 2014 was 4 people (absolute number) with the cause of death due to post partum bleeding and preeclampsia. While infant mortality in kupang district in 2014 was 52 people (absolute numbers). Causes of death of newborns due to neonatal asphyxia, LBW, aspiration, and congenital abnormalities. It was also reported that $\mathrm{K} 1$ coverage was 4760 people (58.66\%) and V4 coverage was 3758 people $(46.31 \%)$. Early detection of risks to mothers and infants by health workers was 679 people $(41.84 \%)$ and by the public as many as 451 people $(27.79 \%)$, and referral of neonatal maternal cases was $149(9.31 \%)^{(5)}$.

Human factors are determinants of public service providers in producing quality services. The quality of service to the community is very dependent on the individual and the system used. Doctors and medical and non-medical support staff serving in health services must understand how to serve consumers well, especially for patients and families, because they are the main consumers of health services. Patient and family complaints about the quality of midwifery services can be caused by various factors, among others, one of them is the low performance of midwives. Assessment of performance includes several factors including observation, size, development and assessment of effectiveness. In individual factors which are one of the factors that influence performance, there are selfmanagement factors that are very important to improve their performance, among others: 1) how individuals determine the behavior of the target to be changed; 2) then individuals are able to monitor their own behavior; 3) individuals choose the procedure to be determined; 4) individuals carry out procedures that have been set by themselves and 5) individuals are able to evaluate the procedures they have carried out continuously. Self management is an effort to manage individuals in order to organize themselves in improving their performance to achieve organizational goals.
According to Quintero et al. ${ }^{(6)}$ who examined the self leadership and effectiveness though in self management teams, found that the ability of a person to lead himself was effective against individual work in the team.

According to Young $\mathrm{K}(2018)^{(6)}$ there are 18 components of self management skills, namely: self assessment, building self confidence, identifying risk factors, choosing good activities, goal setting, building possession.

\section{Material and Method}

This study used an analytical cross sectional design. The target population in this study were all health workers working in the Kupang Regency area. This study took the total population with inclusion criteria: 1) Midwives, 2) worked in the scope of Kupang district health center 3) Willing to be respondents 4) Physical and spiritual health. While the exclusion criteria in this study were respondents who were originally willing to later resign for certain reasons. Sampling using Role of Thumbs, totaling 220 respondents.

Independent variables in this study are individual factors of knowledge and skills. Dependent variable is the performance of midwives in midwifery services including the quality of performance of midwives in the implementation of midwifery care for pregnant women, maternity, newborns and postpartum mothers. Mediator variables are self management, namely self assessment, self analysis, goal setting, self planning, self-implementation, finding social support, self monitoring and self evaluation modified with Varney 7 step midwifery management including the assessment of basic data, interpretation of basic data, anticipate diagnosis/potential problems, immediate action, planning, implementation and evaluation ${ }^{(7)}$. The tool used for this study was a closed questionnaire. In the closed questionnaire the answers are available, with a blue print. This research was carried out in the Kupang District work area which covered a total of 26 Puskesmas in Kupang District, NTT Province of Indonesia.

Very good knowledge of midwives tends to show very good self management $(52.3 \%)$, good midwife knowledge tends to show good self management (77.8\%), sufficient knowledge of midwives tends to show good midwife self management (87.5\%), knowledge of midwives who are less likely to show good midwife self management $(36.4 \%)$, poor midwife knowledge tends to show balanced good and bad midwives self management $(39.2 \%)$. 
Excellent midwife skills tend to show very good midwife self management $(60.5 \%)$, good midwife skills tend to show good midwife self management $(67.3 \%)$, midwife skills that tend to show good midwife performance $(70,3 \%)$, skills of midwives who were less likely to show good midwife performance (78.9\%), poor midwife skills tended to show poor midwife self management $(60.6 \%)$.

The knowledge of midwives about excellent self management tends to have excellent midwifery service performance $(62.6 \%)$, good knowledge, tends to perform very well $(63.0 \%)$, sufficient knowledge of performance tends to be good $(45.8 \%)$, lack of knowledge tends to perform very well $(45.5 \%)$ and poor knowledge of performance tends to be very good $(29.4 \%)$.

The skills of a very good midwife tend to show very good performance $(77.6 \%)$, good midwife skills tend to show good performance $(47.3 \%)$, sufficient skills of midwives tend to perform very well (40.5\%), skills midwives who are less likely to perform very well $(42.1 \%)$, poor midwife skills tend to be balanced between good and very good performance, each (27.3\%).

Very good midwife self management tends to midwife's performance in midwifery services is also very good $(87.7 \%)$, good midwife self-management midwife performance also tends to be good (45.8\%), midwife self-management that is quite midwife performance tends to be good $(39,1 \%)$, midwives' selfmanagement that lacked the performance of midwives tended to be lacking $(40.0 \%)$ and poor self management the performance of midwives tended to be very good $(40 \%)$.

The inner model is including the goodness of fit, which is the value of the $\mathrm{R}$ Square of the dependent latent variable as in table 1 :

\begin{tabular}{|c|l|c|c|}
\hline No & Variable & R Square & $\begin{array}{c}\text { R Square } \\
\text { Adjusted }\end{array}$ \\
\hline 1 & Y. Performance of Midwives & 0.792 & 0.784 \\
\hline 2 & Z. Self Management & 0.795 & 0.788 \\
\hline
\end{tabular}

\section{The influence between variables is as follows:}

a. Knowledge of midwives has a significant effect on midwife's self management, self management has a significant effect on midwife's performance, meaning that knowledge of midwives has a significant effect on midwife's performance through self management. The results of this study indicate that the knowledge of very good midwives tends to influence excellent self-management, which can also influence the tendency of midwives' performance to be very good. This shows that the better the knowledge of midwives about self management can encourage the better implementation of self management, which can influence the performance of midwives to be better.

b. The skills of midwives significantly influence midwife's self management, self management significantly influences the performance of midwives, meaning that the skills of midwives significantly influence the performance of midwives through self management. The results of this study indicate that the skills of very good midwives tend to influence self-management which is very good, which can also influence the tendency of midwives' performance to be very good. This shows that the better the skills of midwives can encourage better self management, which can influence the performance of midwives to be better

c. Self management has a significant effect on the performance of midwives, the results of this study indicate that self management which tends to be very influential also affects the tendency of midwives' performance to be very good. This shows that the better the midwife's self management can encourage the performance of the midwife to be better

d. Knowledge of midwives mediated by self management has a significant effect on the performance of midwives. This shows that the knowledge of midwives mediated by good self management can encourage the performance of midwives to be better.

e. The skills of midwives mediated by self management significantly influence the performance of midwives. This shows that the skills of midwives mediated by good self management can encourage the performance of midwives to be better.

\section{Discussion}

Individual factors (knowledge) of midwives about self management, the results of the study showed that the knowledge of midwives about self-management was mostly good. According to Sharma et al $(2015)^{(3)}$ the assessment is based on a criterion that is self-determined or uses existing criteria. In this study the measured knowledge of midwives about self management. The 
knowledge of midwives in Kupang District Health Center is mostly good, meaning that most midwives already know about self management, have understood it, have applied it, have the ability to analyze and have the ability to evaluate what they are doing.

The individual factors (skills) of midwives about self management, the results of the study showed that the skills of midwives in implementing self management were mostly very good. Skills are the ability to do a physical or mental work. Allan et al (2013) ${ }^{(8)}$ say that skills are aspects of behavior that can be learned through exercises that are used to fill the workplace; skills not only require training, but the basic abilities that each person has can help produce something more valuable faster. Skills are the capacity needed to carry out a series of tasks that develop from the results of training and experience. A person's expertise is reflected by how well someone is carrying out a specific activity, such as operating an equipment, communicating effectively or implementing a business strategy. Most midwives have excellent skills in implementing self management in carrying out Varney's 7-step midwifery management. This can be interpreted that most midwives already have expertise in solving midwifery problems using their logic.

The influence of individual factors (knowledge) midwives on self management gets pvalues $=0.013$, the knowledge ability of midwives to develop self management is very significant, where there are 6 self management skills, namely: problem solving, decision making, resource utilization, the formation of a patien$\operatorname{provider}^{(9)}$ partnership, action planning and selftailoring, this is in line with those recommended by the International Confederation of Midwives

The influence of individual factors (skills) midwives on self management get pvalues $=0.015$, Midwives who have self management will be able to build Building performance skills, do exercises to improve their ability to work. In carrying out the work that is the main task of each employee, performance is displayed in the form of achievement. Effective and efficient performance management is carried out as an activity to help employees discover their potential abilities that are followed up by providing opportunities to make them become achievement through their placement in the field of work or position in accordance with their potential abilities. The performance of individuals is not something that is static, but always dynamic in the sense that it can increase in height or vice versa to decrease or be low. So that everyone wants to achieve progress in work. Progress can only be achieved if someone is able to display satisfactory performance, including higher work productivity.

The influence of individual factors (knowledge) on midwives in implementing self management on the performance of midwives obtained pvalues $=0.02$. This is in accordance with the results of the study from Moattari, et al (2012) ${ }^{(10)}$ who wrote that there was a correlation between physiological factors of knowledge, motivational factors, leadership factors, incentive/ reward factors and co-worker factors with midwives' performance in Iranian services.

The effect of individual midwives (skills) in implementing self management on the performance of midwives obtained pvalues $=0.02$. In line with the study of Karvande, et al (2018) ${ }^{(11)}$ who wrote that the skills of midwives who are often honed make their selfmanagement fundamentally improve performance

The effect of the implementation of self management on the performance of midwives in the health service obtained pvalues $=0.02$. Self management in education, psychology, and business terminology is a method, skill and strategy that can be done by individuals in effectively directing the achievement of the objectives of the activities they perform, including goal setting, planning, scheduling, task tracking, self evaluation, self intervention, self development. In addition, self management is also known as the execution process (decision making).

This study, Varney's 7-step midwifery management was modified with the aim that midwives can provide midwifery services well by doing self-management on their own by modifying self management adapted from Corbin and Charles $(2017)^{(12)}$ consisting of 8 cell steps

\section{Conclusions}

Individual factors (knowledge and skills) directly and indirectly influence the performance of midwives with self-management as mediation.

Conflict of Interest: There is no conflict of interest for authors.

Source of Funding: This research funded by the authors themselves. No other financial support received. 
Ethical Clearance: Ethical reviewed has been done at the ethical standards of the Health Research Ethics Committee Manado Health Polytechnic.

\section{References}

1. Kementerian Kesehatan. PERMENKES No. 28 Tahun 2017. 2017. p. 1-48.

2. Ghahramanian A, Rezaei T, Abdullahzadeh F, Sheikhalipour Z, Dianat I. Quality of healthcare services and its relationship with patient safety culture and nurse-physician professional communication. Heal Promot Perspect [Internet]. 2017;7(3):168-74. Available from: http://dx.doi. org/10.15171/hpp.2017.30

3. Sharma B, Hildingsson I, Johansson E, Prakasamma M, Ramani K V., Christensson K. Do the preservice education programmes for midwives in India prepare confident "registered midwives"? A survey from India. Glob Health Action. 2015;8:19.

4. Franklin N, Melville P. Competency assessment tools: An exploration of the pedagogical issues facing competency assessment for nurses in the clinical environment. Collegian [Internet]. 2015;22(1):25-31. Available from: http://dx.doi. org/10.1016/j.colegn.2013.10.005
5. Dinas Kesehatan Prov. NTT. Profil Kesehatan Prov. NTT Tahun 2015. 2016;12.

6. Young K, Young K. Theories of Personality. Personality and Problems of Adjustment. 2018. 276-300 p.

7. Helen Varney, Jan M. KrIebs CLG. Varney's Midwifery. 2004.

8. Alan S, Ozturk M, Gokyildiz S, Avcibay B, Karatas Y. An evaluation of knowledge of pharmacovigilance among nurses and midwives in Turkey. Vol. 45, Indian Journal of Pharmacology. 2013. p. 616.

9. International Confederation of Midwives. Model Curriculum Outlines for Professional Midwifery Education. 2012;(June 2012): 15.

10. Moattari M, Shafakhah M. Assessing Stages of Exercise Behavior Change, Self Efficacy and Decisional Balance in Iranian Nursing and Midwifery Students. 2013;1(2):121-9.

11. Karvande S, Sonawane D, Samal J, Mistry N. Family planning training needs of auxiliary nurse midwives in Jharkhand, India: Lessons from an assessment. Natl Med J India. 2018;31(2):73-8.

12. Corbin CB, Masurier GC Le, Lambdin DD, Charles B, Masurier GC Le, Dolly D. Fitness For Life. $2007 ; 117$. 
Performance of Midwives with Self Management as a Mediator from the Influence of Individual Factors

ORIGINALITY REPORT



SIMILARITY INDEX
$12 \%$

INTERNET SOURCES
$3 \%$

PUBLICATIONS
$0 \%$

STUDENT PAPERS

PRIMARY SOURCES

1 repository.unair.ac.id

Internet Source

2 www.econstor.eu

Internet Source

3 www.scribd.com

Internet Source

4 www.slideshare.net

Internet Source

5 pubmed.ncbi.nlm.nih.gov

Internet Source

6 journals.iium.edu.my

Internet Source

7 www.ijicc.net

Internet Source

8 quizlet.com

Internet Source 
10 www.pubfacts.com

11 www.hse.ie

12 Anna Gavine, Steve MacGillivray, Fran

McConville, Meena Gandhi, Mary J Renfrew.

"Pre-service and in-service education and

training for maternal and newborn care

providers in low- and middle-income countries:

An evidence review and gap analysis",

Midwifery, 2019

Publication

Chatarina U Wahyuni, Budiono, Lutfia Dwi

Rahariyani, Muji Sulistyowati et al. "Obstacles

for optimal tuberculosis case detection in

primary health centers (PHC) in Sidoarjo district,

East Java, Indonesia", BMC Health Services

Research, 2007

Publication

Letícia Palota Eid, Renato Nery Soriano,

Marcelo Eduardo Batalhão, Lais Palotta

Balderrama, Evelin Capellari Carnio.

"Pharmacotherapy and analysis of gaseous

mediators in hypertensive patients", Revista da 
Escola de Enfermagem da USP, 2015

Publication

15

"Proceedings of the Andalas International Public Health Conference 2017", BMC Public Health, 2017

Publication

Exclude quotes

Off

Exclude matches

Off

Exclude bibliography

On 
Performance of Midwives with Self Management as a Mediator from the Influence of Individual Factors

GRADEMARK REPORT

FINAL GRADE

10

PAGE 1

PAGE 2

PAGE 3

PAGE 4

PAGE 5
GENERAL COMMENTS

Instructor 